\title{
Pseudomugil gertrudae
}

\author{
Assessment by: Hammer, M. \& Kennard, M.
}

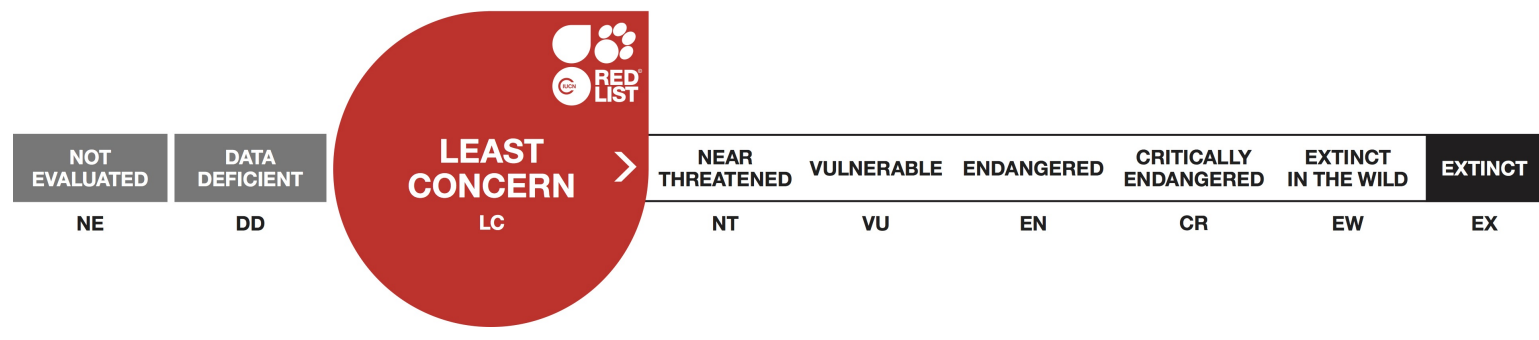

View on www.iucnredlist.org

Citation: Hammer, M. \& Kennard, M. 2019. Pseudomugil gertrudae. The IUCN Red List of Threatened Species 2019: e.T122906064A123382261. http://dx.doi.org/10.2305/IUCN.UK.20193.RLTS.T122906064A123382261.en

Copyright: (C 2019 International Union for Conservation of Nature and Natural Resources Reproduction of this publication for educational or other non-commercial purposes is authorized without prior written permission from the copyright holder provided the source is fully acknowledged.

Reproduction of this publication for resale, reposting or other commercial purposes is prohibited without prior written permission from the copyright holder. For further details see Terms of Use.

The IUCN Red List of Threatened Species ${ }^{T M}$ is produced and managed by the IUCN Global Species Programme, the IUCN Species Survival Commission (SSC) and The IUCN Red List Partnership. The IUCN Red List Partners are: Arizona State University; BirdLife International; Botanic Gardens Conservation International; Conservation International; NatureServe; Royal Botanic Gardens, Kew; Sapienza University of Rome; Texas A\&M University; and Zoological Society of London.

If you see any errors or have any questions or suggestions on what is shown in this document, please provide us with feedback so that we can correct or extend the information provided. 


\section{Taxonomy}

\begin{tabular}{|c|c|c|c|c|}
\hline Kingdom & Phylum & Class & Order & Family \\
\hline Animalia & Chordata & Actinopterygii & Atheriniformes & Pseudomugilidae \\
\hline
\end{tabular}

Taxon Name: Pseudomugil gertrudae Weber, 1911

\section{Taxonomic Source(s):}

Eschmeyer, W.N., Fricke, R., and Ven der Laan, R. (eds.). 2017. Catalog of Fishes: genera, species,

references. Updated 01 November 2017. Available at:

http://researcharchive.calacademy.org/research/ichthyology/catelog/fishcatmain.asp.

\section{Assessment Information}

Red List Category \& Criteria: Least Concern ver 3.1

Year Published: 2019

Date Assessed: $\quad$ February 12, 2019

\section{Justification:}

Listed as Least Concern because it is widespread, common and there are no major threats.

\section{Geographic Range}

\section{Range Description:}

This Australian species occurs in several isolated populations in the Northern Territory and northern Queensland, from Finniss River and Groote Eylandt (Northern Territory) and the Jardine River system, several small creeks at the tip of Cape York Peninsula and the Murray Swamps near Tully (Queensland). This species is also found in Papua New Guinea and Papua Province in Indonesia.

\section{Country Occurrence:}

Native: Australia (Northern Territory, Queensland); Indonesia (Papua); Papua New Guinea 


\section{Distribution Map}

\section{Pseudomugil gertrudae}

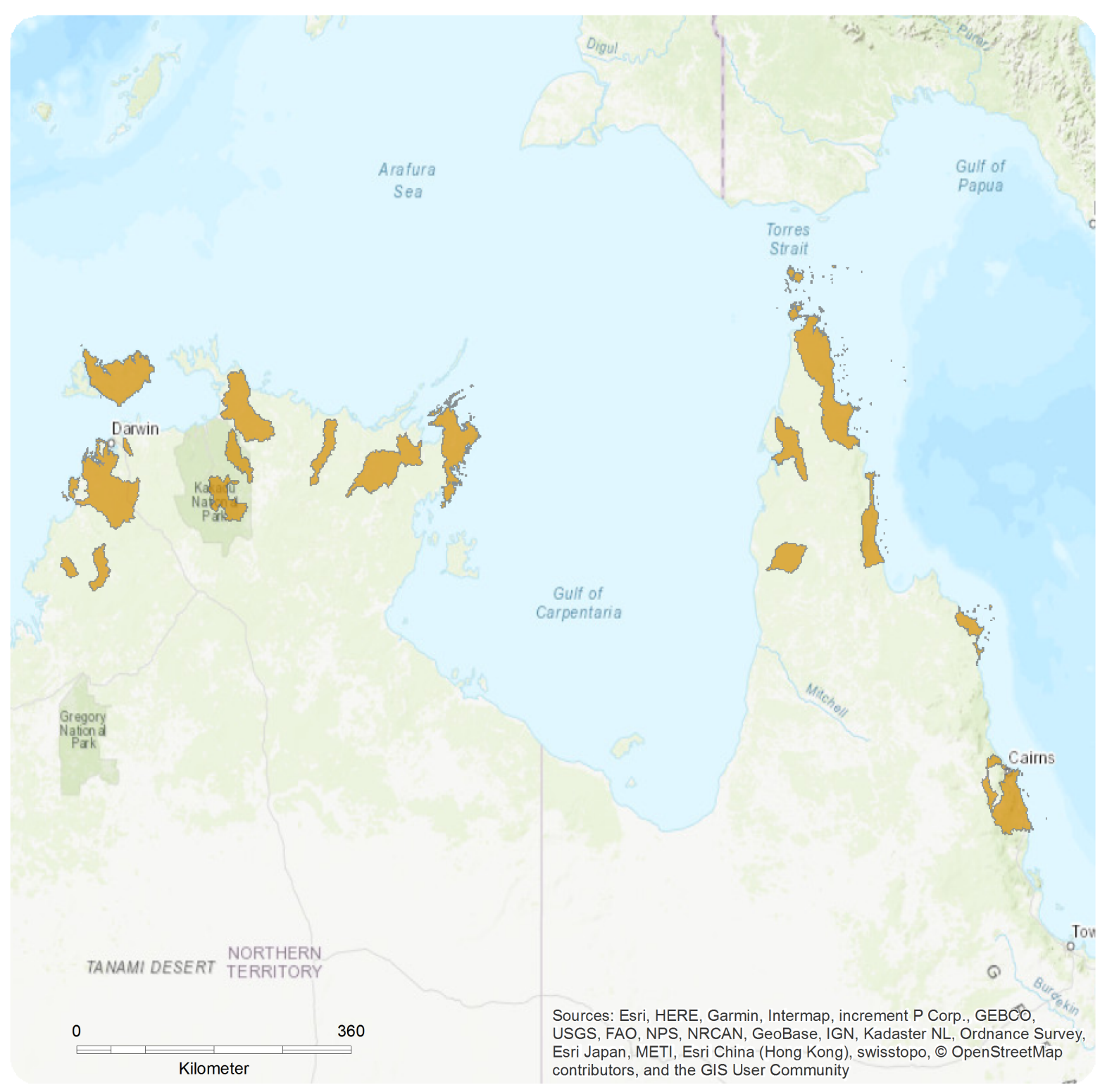

\section{Range}

Extant (resident)
Compiled by:

Lintermans, M. and colleagues 2019 IUCN Red List assessment for Australian freshwater fish.

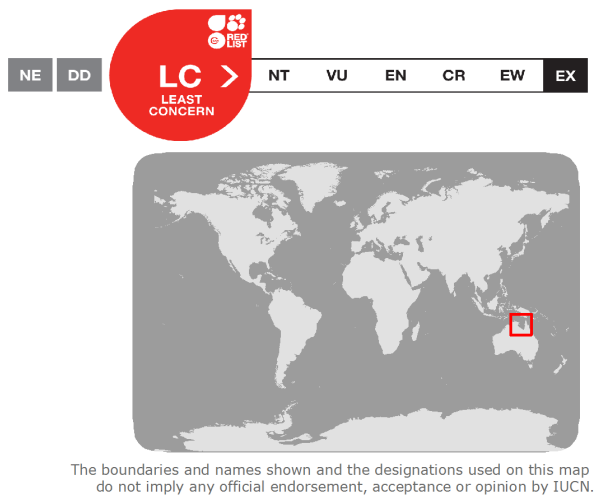




\section{Population}

It is common and widespread in coastal wetlands in northern Australia.

Current Population Trend: Stable

\section{Habitat and Ecology (see Appendix for additional information)}

In Australia it is found in a range of freshwater habitats including small sandy or muddy-bottom creeks, swamps or marshes, shady rainforest streams, lagoons and backwaters. It is commonly found to aggregate in areas with abundant vegetation and woody debris.

Systems: Freshwater

\section{Use and Trade}

A popular aquarium fish, but mostly bred in captivity.

\section{Threats}

There are no major threats to this species overall. There is habitat degradation (floodplains/wetlands) in the wet tropics part of its range for agriculture and infrastructure development.

\section{Conservation Actions (see Appendix for additional information)}

Its range includes several protected areas.

\section{Credits}

Assessor(s): $\quad$ Hammer, M. \& Kennard, M.

Reviewer(s): $\quad$ Kerezsy, A. \& Brooks, S.

Facilitators(s) and Chanson, J.S.

Compiler(s): 


\section{Bibliography}

IUCN. 2019. The IUCN Red List of Threatened Species. Version 2019-3. Available at: www.iucnredlist.org. (Accessed: 10 December 2019).

\section{Citation}

Hammer, M. \& Kennard, M. 2019. Pseudomugil gertrudae. The IUCN Red List of Threatened Species 2019: e.T122906064A123382261. http://dx.doi.org/10.2305/IUCN.UK.2019-

3.RLTS.T122906064A123382261.en

\section{Disclaimer}

To make use of this information, please check the Terms of Use.

\section{External Resources}

For Images and External Links to Additional Information, please see the Red List website. 


\section{Appendix}

\section{Habitats}

(http://www.iucnredlist.org/technical-documents/classification-schemes)

\begin{tabular}{|c|c|c|c|}
\hline Habitat & Season & Suitability & $\begin{array}{l}\text { Major } \\
\text { Importance? }\end{array}$ \\
\hline $\begin{array}{l}\text { 5. Wetlands (inland) -> 5.1. Wetlands (inland) - Permanent } \\
\text { Rivers/Streams/Creeks (includes waterfalls) }\end{array}$ & Resident & Suitable & - \\
\hline $\begin{array}{l}\text { 5. Wetlands (inland) -> 5.7. Wetlands (inland) - Permanent Freshwater } \\
\text { Marshes/Pools (under 8ha) }\end{array}$ & Resident & Suitable & - \\
\hline $\begin{array}{l}\text { 5. Wetlands (inland) -> 5.8. Wetlands (inland) - Seasonal/Intermittent } \\
\text { Freshwater Marshes/Pools (under 8ha) }\end{array}$ & Resident & Suitable & - \\
\hline
\end{tabular}

\section{Conservation Actions in Place}

(http://www.iucnredlist.org/technical-documents/classification-schemes)

\section{Conservation Actions in Place}

In-Place Land/Water Protection and Management

Occur in at least one PA: Yes

\section{Research Needed}

(http://www.iucnredlist.org/technical-documents/classification-schemes)

\section{Research Needed}

1. Research $->1.2$. Population size, distribution \& trends

1. Research -> 1.3. Life history \& ecology 


\section{The IUCN Red List Partnership}

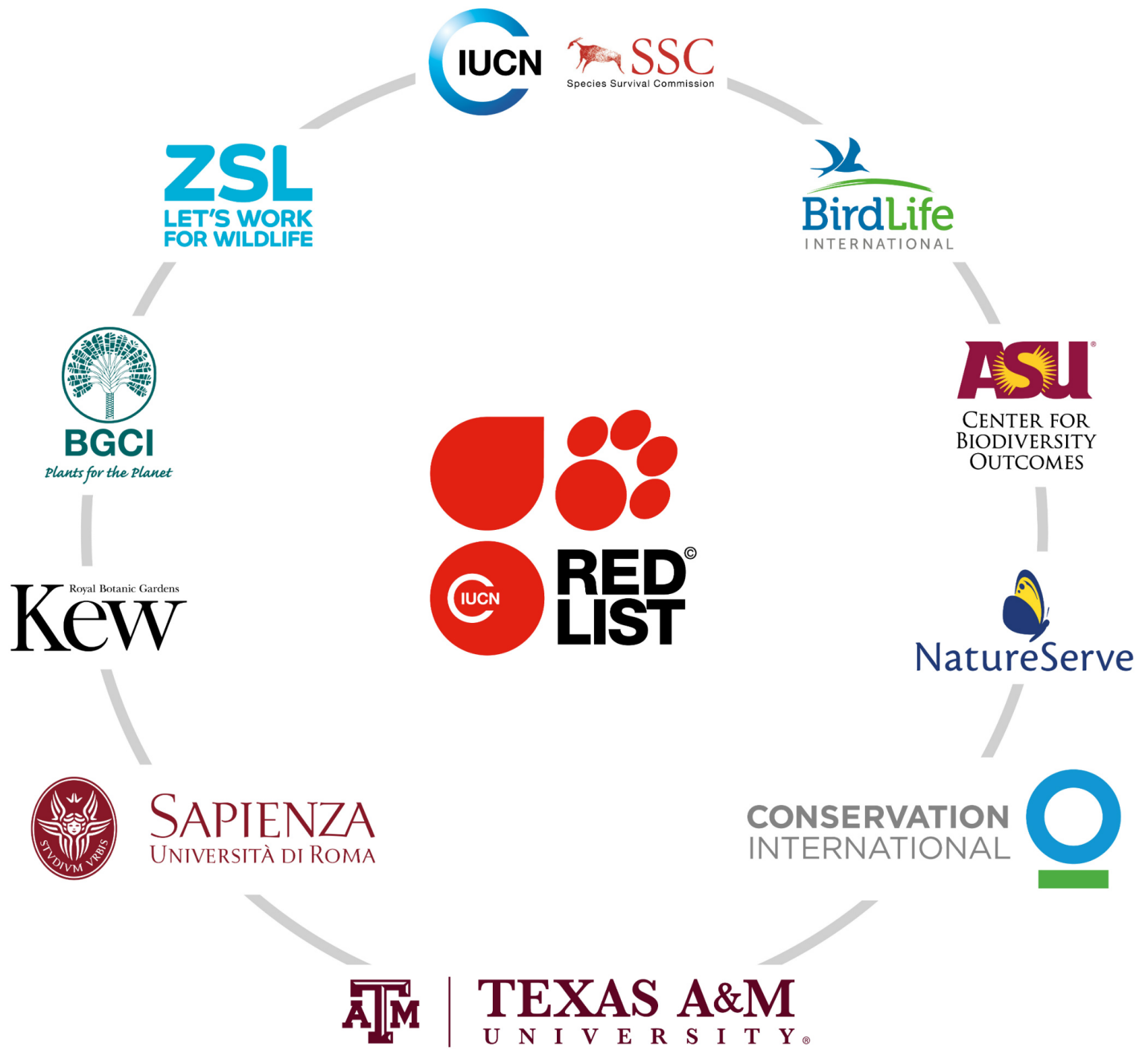

The IUCN Red List of Threatened Species ${ }^{\mathrm{TM}}$ is produced and managed by the IUCN Global Species Programme, the IUCN Species Survival Commission (SSC) and The IUCN Red List Partnership.

The IUCN Red List Partners are: Arizona State University; BirdLife International; Botanic Gardens Conservation International; Conservation International; NatureServe; Royal Botanic Gardens, Kew; Sapienza University of Rome; Texas A\&M University; and Zoological Society of London. 